\title{
The effects of terrorism on economic growth: Panel data approach*
}

\author{
Mehmet Çinar ${ }^{1}$
}

\begin{abstract}
The aim of this study is to examine the effects of terrorism on economic growth experienced worldwide. More precisely these terrorist incidents and its effects on economic growth in most countries are classified according to income groups. In this respect, we conduct a panel study (FE and RE models) to analyze the number of terrorist incidents in these countries and the data range from 2000 to 2015 covering a total of 115 countries. The result of the study is in line with other findings in the literature. Those terrorist attacks are causing a negative impact on the economic growth in most countries, particularly in low-income countries. Generally speaking, the findings show that low-income countries are affected about three times more than high-income countries as a result of these terrorist attacks.
\end{abstract}

Key words: terror, terrorism, economic growth, panel data, FE and RE models

JEL classification: $\mathrm{C23}, \mathrm{F} 52, \mathrm{H1}, \mathrm{O} 4$

\section{Introduction}

Terrorism is as an old concept as human history. The concept of terrorism dates back to combat terrorism against the Romans and the Sicarii in the B. C. 7366 (Dedeoğlu, 2003: 315; Kutlu, 2010: 16). However, to be used as a systematic tool is based on the organization in the Assassins led by Hasan Sabbah, which emerged in the 13th century in the Middle East (Akgün, 2006: 410).

\footnotetext{
* Received: 11-01-2017; accepted: 31-05-2017

1 Associate Professor, Faculty of Economics and Administrative Sciences, Department of Econometrics, Uludag University, 16059 Gorukle Campus, Bursa, Turkey. Scientific affiliation: panel data analysis, time series analysis, applied econometrics, forecasting. Phone: +90224 29411 08.Fax: +90 22429410 03.E-mail:mcinar@uludag.edu.tr.
} 
Terrorism in the modern sense comes from French word "terror" which means extreme fear and anxiety that creates special effects on non-rational individuals and usually means the interplay of unconscious reaction (K1lıç, 2007: 4; Uytun, 2009: 8; Akçay and Çelenay, 2012: 184). Caşın, (2008: 224) describes terrorism as 'a tradition' which dates back to Adam and Eve although the term 'Terror-Terreri' has been etymologically associated with 'Fear (Terror) Reign' following the French Revolution Terror and terrorism are conceptually linked, according to Michael, (2007: 36), terrorism includes people with political views, which he described as having socio-cultural values and norms they want to impose on society through violence. According to another definition, terrorism means actions, which creates fear and chaos via violence or threats of action in the targeted sectors.

Especially, the concept of terrorism is one of the social events winning universality all over the world in recent years (Yeniçeri and Dönmez, 2008: 94). The concept of terrorism, which has a long history, has become one of the international community's unwavering agendas since 1960s. Terrorist acts are, taking place in many parts of the world and the bombing of government buildings, multinational companies, the kidnapping of passenger airplanes and ships; Diplomatic representations, airports, shopping centers, sometime the attack that attacks are conducted against the subway and train stations, government officials, the kidnapping of diplomats and businessmen, or in different ways, such as the assassination of these people and the confrontation of international community (Topal, 2004: 1).

Terror and terrorism can lead to a substantial loss for the economy of the country. These losses are mainly due to uncertainties brought about by the confidence lost with terrorism and transferring a significant portion of the country's resources to military expenditure (Karagöz, 2016: 5). On the other hand, terrorist can also target directly key sectors of economics. These results suggest that the purpose of terrorism, which aims to achieve political and economic demands of the illegitimate way, is a clear indication of the government to intimidate and create fear and horror in the society. In other words, the purposes of terrorism reach a political goal by creating a pressure on political authority and digesting public interest through violence (Karaduman and Batu, 2011: 361).

As stated above, terrorism creates fear and horror in society, pose adversely in many areas, mainly the country's economy. Thus, due to the deep influence of terrorism on social and political life in the country, it also affects economic development adversely (Frey et al., 2007: 2; Uysal et al., 2009: 2). The main reason for the targeting of the economy, the state of economic development (hence government) is that it is the most important indicator of success. In fact, terrorist activities, despite targeting to disrupt the macroeconomic stability in the country, include the economy, the success of these activities is the creation of effective violence in society (Yalçınkaya, 2008: 4). Consisting of weak economic structure in the country, the terrorist organization that facilitates the society and the state 
to manipulate in one direction, it will cause panic and leading to anarchy that dominates the economy. It is a fact that there is a direct and indirect relationship between terrorism and the economy. However, the direction of this relationship may be double-sided to show the interaction. Therefore, counter-terrorism strategy should include the economy.

Another consideration is the influence of terrorism on the factors of production (such as labor, capital) which are in turn negatively affected. Moreover, economic decision units; production, consumption, savings and investment decisions give rise to negative externalities by creating uncertainty in the economic structure (Başıüyük et al., 2012: 33).

One of the important places among the objectives of the country's basic economic policy is economic growth. Simply a country in a given period, the increase in the amount of goods and services produced by expressing economic growth is set to move to the percentage increase in Gross Domestic Product (GDP). GDP is calculated according to the expenditure method using the economic units in a given period by taking into account the spending on final goods and services. Terrorist attack, without doubt, affects it determinants of national GDP and thus show clear evidence that reflect the negative effects on economic growth. For example, distrust that result from terrorism leads to changes in consumption and investment behaviors. More detailed information written in recent years with some of the locals' theoretical studies about terrorism and its economic losses are as follows: Ağır and Kar (2010), Öcal and Yıldırım (2010), Altay et al. (2013) and Ak et al. (2015).

Our study contributes to the existing literature by using panel data analysis and classifying countries by income over the world. While the data used in the study and the countries are identified, the only constraint is the lack of data availability in these countries. Therefore, the data has been obtained from 115 countries and covered over the period of 2000-2015. Within this theoretical and empirical framework, one of the main hypotheses is to test whether increases in terror activities may have impact on economic growth. In other words, the null hypothesis is that there is no relationship between terrorist incidents and economic growth. However, we expect that terrorist incidents have a negative impact on economic growth. The second hypothesis is whether the effect of terrorist activities differs according to the income groups of the countries or it has the same effect in all countries? Meanwhile, the hypothesis that terror event the alternative hypothesis is that the terrorist incidents are effective against the zero hypotheses that countries have no effect on their income levels is being tested. Terrorist incidents are expected to vary according to income groups of countries.

For testing our hypothesis, the rest of the article is structured as follows: Section II includes the relevant theoretical and empirical studies about terrorism and 
economic growth. Section III emphasizes the methodological issues and empirical model. Empirical data and analysis are presented in Section IV. Section V explains the results and political implications and Section VI provides a conclusion.

\section{Literature review}

This section presents the previous studies conducted to look into the aspects of terrorism. Similarly, there are many studies in the literature about the relation between economic variables and terror. It can be seen that the studies on the impact of terrorism on national economies began in the late 1960s (Ak et al., 2015). Some researchers take the various countries, groups of countries and the groups around the world into account while investigating the effects of terrorism on economies. In general, different methods have been used in these studies. However, in such studies, where there are country or periods based and methodological differences, there is a consensus that terror has a negative impact on macroeconomic variables such as economic growth. The main difference observed in these studies is about the impact of violence.

Ak et al. (2015) made a theoretical study that summarizes the literature investigating the relationship between economic growth and terrorism. As a result of theoretical research, they have reached the conclusion that there is an inverse relationship between the literature of terror and the economic growth.

When previous empirical literature is examined, it is seen that empirical studies have generally adopted two econometric methodologies. Some previous articles presented below address terrorism and its economic reflections.

The first econometric approach is based on the studies that use time series data analysis. This approach examines different time periods of various countries. Abadie and Gardeazabal (2003) have examined the relationship between terrorism and GNP in Basque Countries. Their findings conclude that, after the outbreak of terrorism in the late 1960's, GDP per capita in the Basque Countries declined by about 10 percent in comparison with a synthetic control region without terrorism in the 1980's-1990s.

Gupta et al. (2004) investigated the effects of armed conflicts and terrorism on low and middle income countries. The results show that if there is an armed conflict in a country, lower growth and higher inflation can be observed, having adverse effects on tax revenues and investment. Tavares (2004) conducts a systematic investigation of the incidence and economic costs of terrorist attacks at the country level. Tavares (2004) found that rich countries are the most prone to suffer from attacks while their democracies become, if anything, less vulnerable than other countries. Also, a study by World Bank estimates a $4 \%$ GDP decline in the Israeli economy while the 
Palestinian territories suffered a $50 \%$ decline in between 1994 and 2002 (Tavares, 2004: 1044).

Gries et al. (2011) aim to identify the link between the intensity of domestic terrorism and the rate of real GDP per capita growth for Western European countries. They found that economic performance leads to terrorist violence in robust ways only for three out of seven countries. Their findings indicate that the role of economic performance in determining terrorist violence appears to have been important for some countries, whereas all attacked economies have been successful in adjusting to the threat of terrorism.

Using time series analysis, some studies regarding Turkey can be presented as follows. Uysal et al., (2009) have concluded that terrorism negatively affected the economic growth in 1992-2001. According to Sezgin (2003) that examines the defense spending, terrorism and economy, the security and stability in countries is the main requirement for economic development. There are two options for the government to refrain from acts of terrorism. They can either increase the defense spending or education and health spending in order to upgrade the welfare of people who might be associated with terrorist acts.

Y1ldırım and Öcal (2013) investigate the determinants of provincial terrorism in Turkey taking spatial dimension into account for the time period of 19902006. Their results indicate that increases in income and schooling ratio tend to reduce the provincial average of terrorism, whereas an increase in unemployment enhances it.

The second group has adopted the approach of panel data modeling and examined terrorism-growth relationship in more than one country. Blomberg et al. (2004) perform an empirical investigation of the macroeconomic consequences of international terrorism and interactions with alternative forms of collective violence. Their analysis was based on a rich unbalanced panel data set with annual observations on 177 countries from 1968 to 2000. They found that, on average, the incidence of terrorism may have an economically significant negative effect on growth, albeit one that is considerably smaller and less persistent than that associated with either external wars or internal conflict. Gaibulloev and Sandler (2009) examine the impact of terrorism on economic growth in Asia for 19702004. Their panel data estimations show that transnational terrorist attacks had a significant effect on the growth. In other words, Gaibulloev and Sandler (2009) show that an additional terrorist incident per million persons reduces GDP per capita growth by about $1.5 \%$. However, this effect is different between developed and developing Asian countries. Especially for developing Asian countries, transnational terrorism curbs income per capita growth primarily by stimulating government security spending, which diverts resources from more productive private and public investments. 
Meierrieks and Gries (2012) investigate the relationship between economic performance of country and terrorism for 18 Latin American countries from 1970 to 2007. They found that the link between terrorism and economic growth is different according to the development in countries. In other words, the terrorism reduces the growth for less developed countries, but this connection cannot be observed in developed Latin American economies.

Akınc1 et al. (2014) using a total of 152 countries data from 2002 to 2011, consisting of 45 advanced, 77 emerging and 30 underdeveloped countries, made the twostage least squares analysis. According to the results, the terrorist attacks in these three groups of countries are disrupting the growth process by raising the level of inflation. In other words, acts of terrorism negatively affect the growth of inflation. However, this effect is stronger in developing and underdeveloped countries.

Younas (2015) investigates whether international openness limits the negative effect of terrorism on economic growth. The analysis focuses on 120 developing countries over the period of 1976-2008. The findings show that the positive interaction effect of terrorism and globalization suggests that the latter ameliorates the adverse impact of the former on growth. Then this result helps explain why the growth consequences of terrorism vary across nations and hold important policy implications.

Bezić et al. (2016) examine the impact of terrorism on foreign direct investment of the selected European Union (EU) and European Economic Area (EEA) countries. They used dynamic panel data methods over 29 countries from 2000 to 2013. The results indicate that terrorist activities reduce security and confidence of investors in countries exposed to terrorist activities, reducing the inflow of foreign direct investment. These results show a negative indirect relationship between terrorist activities and economy.

Musayev (2016) investigates the potential sources of positive externalities for the relationship between military spending and economic growth using recent advances in panel data estimation methods and a large data-set on military expenditure. The results show that the impact of military expenditure on growth is generally negative as in the literature, but that it is not significantly detrimental for countries facing higher internal threats and for countries with large natural resource wealth once corruption levels are accounted for.

The studies from Turkey investigating the relationship between terrorism and economic growth using panel data analysis are limited. The aim of Altay et al. (2013) is looking into the impacts of terror for the Middle-East countries. They use some macroeconomic variables to identify the impacts of terror. Within the scope of this study, they use panel data analysis and include the data between 1996 and 2010. Their results shows that the terror negatively affects all economic variables, especially tourism. 
Although it is possible to enlarge the number of these studies, Ak et al. (2015) says that the studies in literature are insufficient, and that they should be increased through new approaches and methods. As can be seen, studies reveal a clear and unambiguous manner that terrorism has negative effects on the national economy and macroeconomic variables. This study aims to demonstrate the adverse effects of terrorism on the country's economy, which is classified by low, medium and high income economies. This study will greatly contribute to the existing literature as it addresses the income distribution of countries and has a relatively large number of data.

\section{Methodology of analysis}

In the study, because the time dimension $(\mathrm{T}=16)$ is smaller than the individual dimension $(\mathrm{N}=115)$, traditional panel data approach is used. Traditional panel data models are discussed in three basic categories. The first one is Pooled Panel Data Model (POLS). In POLS, the effects of time and individuals dimensions are not important, and panel data are used as a sample. Simply, POLS model is shown as follows:

$$
Y_{i t}=\alpha+\beta X_{i t}+\varepsilon_{i t}
$$

Where $\alpha$ is constant term of common effects, $\beta$ is slope parameters of common effects and $\varepsilon_{i t} \sim N\left(0, \sigma_{\varepsilon}^{2}\right)$ is normally distributed error term. When the panel data is concerned, it would often be unrealistic to assume that it has no effects on individuals.

Therefore, the effect of the individuals is taken into account in two different ways. The first is the Fixed Effects Model (FEM). In FEM, it is assumed that the effects of individuals are correlated with the independent variables in the panel data model. Therefore, the FEM reveals that the individual's effect will be shown as follows:

$$
Y_{i t}=\alpha_{i}+\beta X_{i t}+\varepsilon_{i t}
$$

In this equation (3), $\alpha_{i}$ shows the constant term of individuals' effects. FEM demonstrates the individual effects using the dummy variables. Therefore, for the estimation of FEM is used the Least Squares Dummy Variables (LSDV). Using a great number of dummy variables in the model leads to many problems, especially, the problem of degrees of freedom. In this case, we can use Random Effects Model (REM), where the effects of individuals and the independent variables are uncorrelated as follows:

$$
Y_{i t}=\alpha_{i}+\beta X_{i t}+\varepsilon_{i t}
$$


Where $\alpha_{i}=\alpha+u_{i}$ and the individuals effects are regarded as a component of the random term. Then, the REM can be rewritten as follows:

$$
Y_{i t}=\alpha+\beta X_{i t}+w_{i t}
$$

Where $w_{i t}=u_{i}+\varepsilon_{i t}$, and $\varepsilon_{i t} \sim N\left(0, \sigma_{\varepsilon}^{2}\right), u_{i} \sim N\left(0, \sigma_{u}^{2}\right)$ and $w_{i t} \sim N\left(0, \sigma_{\varepsilon}^{2}+\sigma_{u}^{2}\right)$.

The most important stage is determining the appropriate model among POL, FEM and REM models. For this purpose, despite the use of non-formal approaches, this decision would be more accurate to reveal the three-stage process. Tests are used to determine the appropriate model structure with several steps: In the first stage, Chow F-homogeneity test is used in order to decide between Pooled OLS (POLS) and Fixed Effects (FE) models. If the null hypothesis is rejected, this means that the Fixed Effects Model (FEM) is appropriate. On the contrary, if the null hypothesis is non-rejected, POLS model should be used. In the second stage, LM-type tests are used to decide between Pooled OLS (POLS) and Random Effects (RE) - Honda LM test is used in our study. If the null hypothesis is rejected, this means that the Random Effects (REM) model is valid. Otherwise, the POLS models must be used. Finally, Hausman test is used in order to choose between Fixed Effects (FE) and Random Effects (RE). If the null hypothesis is rejected, Fixed Effects Model (FEM) should be used. Otherwise, REM will be the appropriate model.

\section{Empirical data and analysis}

\subsection{Empirical data}

The study takes into account all the countries in the world whose data is available to demonstrate the impact of terrorist incidents on economic growth. Therefore, in this study, the data of terrorist incidents on economic growth ranging from 2000-2015 in 115 countries have been analyzed. The detailed time spans of all the observed variables, along with their basic descriptive statistics can be seen in Table A1 in Appendices. The countries and their income status used in the study are shown in Table 1. 
Mehmet Çinar $・$ The effects of terrorism on economic growth: Panel data approach

Table 1: Countries and their income status in 2016

\begin{tabular}{|c|c|c|c|c|}
\hline \multicolumn{2}{|c|}{$\begin{array}{l}\text { High Income Countries } \\
\qquad(>12735 \$)\end{array}$} & \multirow{2}{*}{\begin{tabular}{|l}
\multicolumn{1}{c}{$\begin{array}{c}\text { Upper Middle } \\
\text { Income Countries } \\
(4126 \$-12735 \$)\end{array}$} \\
Belarus
\end{tabular}} & \multirow{2}{*}{\begin{tabular}{|c|}
$\begin{array}{c}\text { Lower Middle } \\
\text { Income } \\
\text { Countries } \\
(1045 \$-4125 \$) \\
\text { Bangladesh }\end{array}$ \\
\end{tabular}} & \multirow{2}{*}{\begin{tabular}{|c|c}
$\begin{array}{c}\text { Low Income } \\
\text { Countries } \\
(<1045 \$)\end{array}$ \\
Benin
\end{tabular}} \\
\hline Argentina & Latvia & & & \\
\hline Australia & Lithuania & Belize & Bolivia & Burkina Faso \\
\hline Austria & Luxembourg & Botswana & Cameroon & Burundi \\
\hline Bahrain & Malta & Brazil & $\begin{array}{l}\text { Egypt, Arab } \\
\text { Rep. }\end{array}$ & Cambodia \\
\hline Barbados & Netherlands & Bulgaria & El Salvador & Guinea-Bissau \\
\hline Belgium & New Zealand & China & Georgia & Haiti \\
\hline $\begin{array}{l}\text { Brunei } \\
\text { Darussalam }\end{array}$ & Norway & Costa Rica & Guatemala & Madagascar \\
\hline Canada & Poland & \begin{tabular}{|l|} 
Dominican \\
Republic \\
\end{tabular} & Honduras & Malawi \\
\hline Croatia & Portugal & Ecuador & India & Mali \\
\hline Cyprus & Qatar & Fiji & Indonesia & Mozambique \\
\hline Czech Republic & \begin{tabular}{|l} 
Russian \\
Federation \\
\end{tabular} & Jamaica & Kenya & Nepal \\
\hline Denmark & Saudi Arabia & Macedonia, FYR & Kyrgyz Republic & Niger \\
\hline Estonia & Singapore & Malaysia & Lao PDR & Rwanda \\
\hline Finland & Slovak Republic & Maldives & Lesotho & Sierra Leone \\
\hline France & Slovenia & Mauritius & Morocco & Togo \\
\hline Germany & Spain & Mexico & Nicaragua & Uganda \\
\hline Greece & Sweden & Namibia & Pakistan & \\
\hline Hungary & Switzerland & Panama & Philippines & \\
\hline Iceland & $\begin{array}{l}\text { Trinidad and } \\
\text { Tobago }\end{array}$ & Paraguay & Senegal & \\
\hline Ireland & \begin{tabular}{|l|} 
United Arab \\
Emirates
\end{tabular} & Peru & Sri Lanka & \\
\hline Israel & United Kingdom & Romania & Vanuatu & \\
\hline Italy & United States & South Africa & Vietnam & \\
\hline Japan & Uruguay & Suriname & Yemen, Rep. & \\
\hline Korea, Rep. & Venezuela, RB & Thailand & Zambia & \\
\hline Kuwait & & Tunisia & & \\
\hline & & Turkey & & \\
\hline
\end{tabular}

Sources: World Development Indicators, 2016

According to Table 1, the study comprises of 115 countries, with 49 high-income, 26 over middle-income, 24 lower middle-income and 16 low-income countries. When examining Table 1, according to World Bank indicators, countries with per capita annual income of $\$ 12,735$ are defined as high-income countries. 
Nevertheless, countries with per capita annual income of $\$ 1,045$ are classified as low-income countries while countries with average per capita income of $\$ 4,125$ are defined middle-income countries (World Development Indicators, 2016). As can be seen from Table 1, Turkey is located in above average income country class by the end of 2015. (Annual per capita income of \$9,257).

The data used in this study was prepared as follows. The economic growth (GRW) obtained from International Financial Statistics (IFS) for 115 countries in the periods of 2000-2015 is measured in percentage. However, the data of terrorist incidents in these countries was obtained from the University of Maryland Global Terrorism Database (GTD) ${ }^{2}$.

While the data used in this study and the countries are identified, the only constraint is the lack of data availability in these countries. Therefore, the data $(115 * 16=1840$ in total) has been obtained from 115 countries and covered over the period of 20002015. Terror index (TERROR) is formed as $\log (1+$ number of events), based on the work of Eckstein and Tsiddon (2004) and Persitz (2006). The economic growth (GRW) variable shows annual growth rates of the countries. All econometrical analyses were run on Econometric Views (EViews) software package.

\subsection{Empirical analysis}

The first part of this result is to investigate the stationarity properties of the economic growth (GRW) and terror index (TERROR) variables. Accordingly, Table 2 shows the results of the three panel unit root tests. The LLC takes the existence of a common unit root into consideration, while IPS and Fisher-ADF tests are conducted to examine the existence of the individual unit root. In the three units root test, accepting the null hypothesis shows that the series is non-stationary, whereas the alternative hypotheses shows that the variables are stationary.

Moreover, in Table 2 the panel unit root tests are conducted on both the four income groups and in all the countries (115). Accordingly, the null hypothesis in all countries and all the income groups are rejected for all the tests. In other words, economic growth (GRW) and the terror index (TERROR) series are stationary on both the income groups and for all the countries, implying that there is no unit root in the series. Namely, the effects of random shocks on both series were found to be temporary. Therefore, the results of the model estimation can be submitted.

$\overline{2}$ For more information about Global Terrorism Database (GTD) can be viewed on https://www.start. umd.edu/gtd/. 
Mehmet Çinar - The effects of terrorism on economic growth: Panel data approach

Table 2: Panel unit root tests results

\begin{tabular}{|c|c|c|c|}
\hline Series & Panel Unit Root Tests & GRW & TERROR \\
\hline \multirow{3}{*}{$\begin{array}{l}\text { High Income } \\
\text { Countries }\end{array}$} & LLC & $-14.1195^{\mathrm{a}}$ & $-7.6257^{\mathrm{a}}$ \\
\hline & IPS & $-9.9714^{\mathrm{a}}$ & $-8.5613^{\mathrm{a}}$ \\
\hline & $\begin{array}{l}\text { Fisher-ADF: MW \& } \\
\text { Choi Z }\end{array}$ & $271.332^{a} \&-9.8522^{a}$ & $236.060^{\mathrm{a}} \&-7.4943^{\mathrm{a}}$ \\
\hline \multirow{3}{*}{$\begin{array}{l}\text { Upper Middle } \\
\text { Income } \\
\text { Countries }\end{array}$} & LLC & $-11.0018^{\mathrm{a}}$ & $-4.3146^{\mathrm{a}}$ \\
\hline & IPS & $-7.9180^{\mathrm{a}}$ & $-5.1300^{\mathrm{a}}$ \\
\hline & $\begin{array}{l}\text { Fisher-ADF: MW \& } \\
\text { Choi Z }\end{array}$ & $159.505^{a} \&-7.375822^{a}$ & $97.5950^{\mathrm{a}} \&-4.7765^{\mathrm{a}}$ \\
\hline \multirow{3}{*}{$\begin{array}{l}\text { Lower Middle } \\
\text { Income } \\
\text { Countries }\end{array}$} & LLC & $-5.4611^{\mathrm{a}}$ & $-6.9802^{a}$ \\
\hline & IPS & $-4.9771^{a}$ & $-5.1605^{\mathrm{a}}$ \\
\hline & $\begin{array}{l}\text { Fisher-ADF: MW \& } \\
\text { Choi Z }\end{array}$ & $114.668^{a} \&-3.0852^{a}$ & $113.188^{\mathrm{a}} \&-5.1236^{\mathrm{a}}$ \\
\hline \multirow{3}{*}{$\begin{array}{l}\text { Low Income } \\
\text { Countries }\end{array}$} & LLC & $-3.7186^{\mathrm{a}}$ & $-58.3225^{a}$ \\
\hline & IPS & $-5.1451^{\mathrm{a}}$ & $-22.4392^{a}$ \\
\hline & $\begin{array}{l}\text { Fisher-ADF: MW \& } \\
\text { Choi Z }\end{array}$ & $77.2850^{\mathrm{a}} \&-4.8137^{\mathrm{a}}$ & $149.136^{\mathrm{a}} \&-8.2374^{\mathrm{a}}$ \\
\hline \multirow{3}{*}{ All Countries } & LLC & $-10.7154^{a}$ & $-60.2144^{\mathrm{a}}$ \\
\hline & IPS & $-12.2284^{\mathrm{a}}$ & $-21.0213^{\mathrm{a}}$ \\
\hline & $\begin{array}{l}\text { Fisher-ADF: MW \& } \\
\text { Choi Z }\end{array}$ & $525.608^{a} \&-10.3604^{a}$ & $693.161^{a} \&-15.3513^{a}$ \\
\hline
\end{tabular}

Note: ${ }^{a}$ significant at $1 \%$.

Source: Author's calculation

As previously stated, considering the availability of data for all countries, especially in the series taken as a whole (All Countries), the Fixed Effects (FE) model will intuitively be more appropriate. However, the use of a systematic approach can also be preferred in order to make judgments in a more subjective way. Table 3 illustrates the specification test results.

Table 3: Specification tests

\begin{tabular}{|l|l|r|r|r|}
\hline \multicolumn{1}{|c|}{ Series } & $\begin{array}{c}\text { Suitable } \\
\text { Models }\end{array}$ & CHOW F & $\begin{array}{c}\text { HONDA } \\
\text { LM }\end{array}$ & $\begin{array}{c}\text { HAUSMAN } \\
\text { CHI-SQUARE }\end{array}$ \\
\hline High Income Countries & RE Model & $3.9230^{\mathrm{a}}$ & $11.5861^{\mathrm{a}}$ & 0.01104 \\
\hline Upper Middle Income Countries & RE Model & $2.1083^{\mathrm{a}}$ & $3.3458^{\mathrm{a}}$ & 0.3160 \\
\hline Lower Middle Income Countries & FE Model & $6.4936^{\mathrm{a}}$ & $10.7060^{\mathrm{a}}$ & $14.4326^{\mathrm{a}}$ \\
\hline Low Income Countries & FE Model & $2.1407^{\mathrm{a}}$ & $2.0166^{\mathrm{b}}$ & $4.2111^{\mathrm{b}}$ \\
\hline All Countries & FE Model & $3.2832^{\mathrm{a}}$ & $13.8233^{\mathrm{a}}$ & $10.0738^{\mathrm{a}}$ \\
\hline
\end{tabular}

Note: ${ }^{\text {a }}$ significant at $1 \%,{ }^{b}$ significant at $5 \%$.

Source: Author's calculation 
In Table 3, the results came out as expected, considering that all the countries in the last row of the Table 3 shows that the Fixed Effects (FE) model is found to be suitable.

Likewise, the Fixed Effects (FE) is an appropriate model for both lower middle income and low-income countries. However, the situation is different from the upper middle-income and high-income countries. The Random Effects (RE) was determined to be more appropriate for countries with these two income groups. In each case, after determining the appropriate model structures, then the estimation process can begin. However, the estimation results of the panel data models can be used in case of the provision of econometric assumptions. Therefore, after the panel data regression model, the estimation must be applied on cross sectional dependence, autocorrelations, and heteroscedasticity. The results of these tests are given in Table 4.

Table 4: Test results of the econometric assumptions

\begin{tabular}{|l|c|c|c|c|c|c|c|c|c|}
\hline \multirow{2}{*}{ Series } & \multicolumn{2}{|c|}{ Cross sectional dependence } & \multicolumn{2}{c|}{ Autocorrelations } & \multicolumn{3}{c|}{ Heteroscedasticty } \\
\cline { 2 - 10 } & Friedman & Frees & Pesaran & LM & LM5 & W0 & W10 & W50 & Greene \\
\hline $\begin{array}{l}\text { High } \\
\text { Income } \\
\text { Countries }\end{array}$ & $316.674^{\mathrm{a}}$ & $8.545^{\mathrm{a}}$ & $64.810^{\mathrm{a}}$ & $6.960^{\mathrm{a}}$ & $120.4^{\mathrm{a}}$ & $4.9635^{\mathrm{a}}$ & $4.6227^{\mathrm{a}}$ & $3.9505^{\mathrm{a}}$ & - \\
\hline $\begin{array}{l}\text { Upper } \\
\text { Middle } \\
\text { Income } \\
\text { Countries }\end{array}$ & $129.718^{\mathrm{a}}$ & $2.009^{\mathrm{a}}$ & $24.653^{\mathrm{a}}$ & $2.730^{\mathrm{a}}$ & 1.250 & $2.8643^{\mathrm{a}}$ & $1.7273^{\mathrm{b}}$ & $1.6394^{\mathrm{a}}$ & - \\
\hline $\begin{array}{l}\text { Lower } \\
\text { Middle } \\
\text { Income } \\
\text { Countries }\end{array}$ & $68.169^{\mathrm{a}}$ & $1.443^{\mathrm{a}}$ & $14.320^{\mathrm{a}}$ & $10.6438^{\mathrm{a}}$ & $3.2625^{\mathrm{a}}$ & - & - & - & $3687.92^{\mathrm{a}}$ \\
\hline $\begin{array}{l}\text { Low } \\
\text { Income } \\
\text { Countries }\end{array}$ & $26.881^{\mathrm{b}}$ & 0.156 & $2.409^{\mathrm{b}}$ & 2.5044 & $1.5825^{\mathrm{c}}$ & - & - & - & $98439.56^{\mathrm{a}}$ \\
\hline $\begin{array}{l}\text { All } \\
\text { Countries }\end{array}$ & $331.421^{\mathrm{a}}$ & $7.280^{\mathrm{a}}$ & $78.066^{\mathrm{a}}$ & $22.7417^{\mathrm{a}}$ & $4.7688^{\mathrm{a}}$ & & - & - & $1.7 \mathrm{E}+5^{\mathrm{a}}$ \\
\hline
\end{tabular}

Note: ${ }^{\mathrm{a}}$ significant at $1 \%,{ }^{\mathrm{b}}$ significant at $5 \%$, and ${ }^{\mathrm{c}}$ significant at $10 \%$.

Source: Author's calculation

The test results given in Table 4 are analyzed; and the estimated error of the models for almost all the data groups appear to be deviated from econometric assumptions at least $10 \%$. Thus, standard FE and RE estimates are consistent, but they are not efficient, showing that the estimated standard error is biased. Namely, the predicted results would not be appropriate to use in this state. 
In that case, the model must be estimated using a new method that can produce consistent standard errors against these problems. In this approach, the standard errors are weighed according to the panel. Thus, the new standard errors are consistent and robust to econometrical problems such as cross-sectional dependence, autocorrelations, and heteroscedasticity. The robust estimation results of panel data models are given in Table 5. The detailed results are presented from Table A2 to Table A6 in Appendices.

Table 5: Panel estimation results with robust standard errors

\begin{tabular}{|l|r|r|r|}
\hline \multicolumn{1}{|c|}{ Series } & \multicolumn{1}{c|}{ Constant } & \multicolumn{1}{c|}{ Slope } & \multicolumn{1}{c|}{$\mathrm{R}^{2}$} \\
\hline High Income Countries (RE) & $2.9796^{\mathrm{a}}$ & -0.1981 & 0.002 \\
\hline Upper Middle Income Countries (RE) & $4.4133^{\mathrm{a}}$ & -0.2624 & 0.004 \\
\hline Lower Middle Income Countries (FE) & $5.2524^{\mathrm{a}}$ & $-0.3429^{\mathrm{a}}$ & 0.50 \\
\hline Low Income Countries (FE) & $5.9859^{\mathrm{a}}$ & $-0.5225^{\mathrm{b}}$ & 0.36 \\
\hline All Countries (FE) & $4.2682^{\mathrm{a}}$ & $-0.3673^{\mathrm{a}}$ & 0.48 \\
\hline
\end{tabular}

Note: ${ }^{\text {a }}$ significant at $1 \%,{ }^{b}$ significant at $5 \%$.

Source: Author's calculation

The estimated results in Table 5 reveal that the slope parameters of the models for all the groups in all countries are found to be negative. All the negative estimated slope parameters are appropriate for the economic literature as expected. Thus, the terrorist attacks in all the countries presented have a negative effect on economic growth as expected. However, by looking into each model in detail, the following conclusions were reached.

On the last line of the Table 5 for the case of all the 115 countries, if terrorist attacks are held constant, average growth rate of the countries is $4.268 \%$ between 2000 2015 years. On the other hand, if there is a $1 \%$ increase in the terrorist incidents in the country, it will lead to about $0.3673 \%$ decrease in the average growth rate. Here, both the constant and the slope parameters were statistically significant at the $1 \%$ level.

For the countries in low-income groups, if the terror variable is held constant, average growth rate of low-income countries is $5.98 \%$. This growth rate is as high a growth rate as expected in terms of the average low-income countries. When there is a $1 \%$ increase in average of terrorist incidents, this will lead to about $0.5225 \%$ decrease in low-income countries' economic growth. Also, both constant and slope parameters were statistically significant at the $5 \%$ and $1 \%$ level respectively.

The results obtained for lower middle-income countries are not very different from the low-income countries. That is, when terrorist attacks are held constant, the 
average growth rate of lower middle-income countries is $5.25 \%$. If there is a $1 \%$ increase in terrorist incidents in lower middle-income countries, this will lead to about $0.3429 \%$ on average. Both constant and slope parameters were statistically significant at the $1 \%$ level.

If terror events are held constant for the upper middle-income countries (such as Turkey), the average growth of countries is $4.4 \%$. When there is a $1 \%$ increase in terrorist incidents in the countries, it is seen that there is an average decrease of $0.26 \%$ in economic growth of these countries. However, in this case, the constant parameters are found to be significant at the $1 \%$ level while the slope parameter was not statistically significant. Similar situations are also valid in high-income countries.

Likewise, when the terrorist attacks in high-income countries remain constant, average growth rate is $2.98 \%$. On other hand, a $1 \%$ increment in terrorist attacks in high-income countries, the decline in economic growth in these countries is by $0.20 \%$. However, in high-income countries the constant parameters are significant at the level of $1 \%$; the slope parameter was not found to be statistically significant.

\section{Results and discussion}

Is there a relationship between economic growth and terror activities in the world? If so, does the effect on the economic growth of terrorist incidents differ according to the income groups in countries? This paper focuses on these two questions. The findings of this empirical research approve that there is a negative relationship between economic growth and terror activities. More clearly, if there is a decrease in the terrorist incidents in the country, it will lead to an increase in the average growth rate.

The applied panel unit root test results show that the null hypothesis in all countries and all the income groups are rejected for all the tests. In other words, economic growth (GRW) and the terror index (TERROR) series are stationary on both the income groups and for all the countries, implying that there is no unit root in the series. These results show that the impacts of random shocks that occur over time in the series are temporary in both terrorist incidents and economic growth series. In that case, the effects of terrorist incidents in the country are eliminated in the following period. Similarly, random shocks on growth are not effective. These results are similar to Eckstein and Tsiddon (2004), Gaibulloev and Sandler (2009), Akınc1 et al. (2014), Younas (2015) and Bezić et al. (2016).

The results of the analysis came out as expected. Considering all the countries, the Fixed Effects (FE) model is found to be suitable. These results are similar to Gaibulloev and Sandler (2009). Likewise, the Fixed Effects (FE) is an appropriate model for both lower middle income and low-income countries. However, it is 
different from the upper middle-income and high-income countries. The Random Effects (RE) was determined to be more appropriate for countries with these two income groups.

The estimated results reveal that the slope parameters of the models for all the groups in all countries are found to be negative. All the negative estimated slope parameters are appropriate to the economic literature as expected. Thus, the terrorist attacks in most of these countries have a negative effect on economic growth as expected. The results obtained in this study support the results obtained from Gaibulloev and Sandler (2009), Akınc1 et al. (2014), Younas (2015) and Bezić et al. (2016).

In the case of all 115 countries, if terrorist attacks are held constant, average growth rate of the countries is $4.27 \%$ between 2000-2015 years. For low-income groups, the average growth rate is $5.98 \%$. The average growth rate of lower middle-income countries is $5.25 \%$. In the upper middle-income countries (such as Turkey), the average growth is $4.4 \%$. Moreover, the average growth rate in the high-income countries is $2.98 \%$. Note that as the level of income increases, the average growth rates of countries fall. As a matter of fact, these results are suitable for economic expectations and related literature.

On the other hand, when the magnitudes of the slope coefficients are examined, the following conclusion can be drawn: As the income level of the countries increases, the effects of terrorist incidents on economic growth diminish. The results obtained in this study support the view of Younas (2015). According to Younas (2015), the economic structure of developed countries is to increase the effect of suppressing the growth of terrorism in order to avoid the possibility. On the other hand, these countries will eliminate the shock caused by terrorism with strong fiscal and monetary policy tools. The smaller economies of developing countries are deprived of such opportunities.

Considering the model estimation results as a whole, it is useful to say the terrorist incidents in a country create a negative impact on growth rate. However, this effect in low-income countries is about three times greater than in high-income countries. Therefore, it can be concluded that the effect of terrorism is felt more on low-income countries. The results obtained in this study support results obtained from the literature by Gaibulloev and Sendler (2009), Meierrieks and Gries (2012), Akınc1 et al. (2014) and Younas (2015).

\section{Conclusion}

As terrorism can serve many purposes, it can cause damage to the country in many ways. In this study, the impacts on economic growth in most countries as a result of terrorist incidents were investigated using panel data. The literature research 
shows that economic growth is inversely related to terrorism. The study covers a total of 115 countries for years 2000-2015, and the result of the panel data model takes income groups into account. As expected from the literature, it was found that there is a negative effect of terrorist incidents on economic growth in most of the countries in this study as well. However, this effect in low-income countries is about three times greater than in high-income countries.

The main contribution of this paper is that there is a relationship of terrorist incidents and economic growth. However, this relationship changes by income groups. Therefore, the hypothesis of this study is approved. The main limitation of the presented models can be methodologically complemented and developed. Depending on the objectives and interests of interested professionals, it is possible to add new variables (such as: technology, human capital, capital formation, exchange rate, interest rate, foreign direct investment etc.) to the models. In addition, the model can be estimated by alternative methods such as dynamic models, and the results can be compared.

Terrorism affects countries in many ways. In fact, reversing this effect can act as an antidote to the reduction of terrorist incidents. Many countries such as Turkey prefer (or are forced) to have a military combat as a direct method of tackling terrorism. However, this approach increases the problem over time instead of reducing it. Unfortunately, this increase is happening all over the world. Therefore, the study actually suggests the economic growth as an indirect instrument for combating terrorism. As can be understood from the results, the increase in income level will cause individuals to stay away from illegal tendencies.

\section{References}

Abadie, A., Gardeazabal, J. (2003) "The Economic Costs of Conflict: A Case Study of the Basque Country", American Economic Review Vol 93, No. 1, pp. 113132, doi: $10.1257 / 000282803321455188$.

Ağır, H., Kar, M. (2010) "Terörizmin Makroekonomik Sonuçları Üzerine Bir Değerlendirme". Finans Politik \& Ekonomik Yorumlar, Vol. 47, No. 539, pp. 1332. Available at: <http://www.huseyinagir.com/wp-content/uploads/2014/10/ Ter\%C3\%B6rizmin-Makroek onomik-S onu \%C3\%A 71ar\%C4\%B 1\%C3\%9Czerine.pdf> [Accessed: March 29, 2017].

Ak, M. Z., Aydın, M. K., Dinar, M. (2015) “Terör ile Büyüme Arasındaki İlişki: Literatür İncelemesi” Bilgi, Vol. 31, pp. 1-16. Available at: <https://www. researchgate.net/publication/301205003> [Accessed: March 29, 2017].

Akçay, E. Y., Çelenay, Ö. E. (2012) “Terör ve Medya İlişkisinin 2003 Y1lında İstanbul'da Meydana Gelen Saldırılar Örneğiyle İncelemesi”, Nevşehir Üniversitesi Sosyal Bilimler Enstitüsü Dergisi, Vol. 2, pp. 183-197. Available at: <http:// 
acikerisim.hakkari.edu.tr:8080/xmlui/handle/123456789/170> [Accessed: March 29, 2017].

Akgün, B. (2006) "Küresel terör: mit mi?, gerçek mi?". In Gökçe O., Demiray U. ed., Terörün görüntüleri, görüntülerin terörü, Konya: Çizgi Kitabevi.

Akıncı, M., Yüce Akıncı, G., Yılmaz, Ö. (2014) "Terörizmin Enflasyon ve Ekonomik Büyüme Üzerindeki Etkileri: Panel İki Aşamalı En Küçük Kareler Yöntemi”, Uluslararası Güvenlik ve Terörizm Dergisi, Vol. 5, No. 1, pp. 1-24. Available at: $<$ http://kutuphane.dogus.edu.tr/mvt/pdf.php?pdf=0016022> [Accessed: March 29, 2017].

Altay, H., Ekinci, A., Peçe, M. A. (2013) "Ortadoğu'da Terörün Ekonomik Etkileri: Türkiye, Misır ve Suudi Arabistan Üzerine Bir İnceleme", Dumlupınar Üniversitesi Sosyal Bilimler Dergisi, Vol. 37, pp. 267-288. Available at: <http:// dergipark.gov.tr/download/article-file/55895> [Accessed: March 29, 2017].

Başıbüyük, O., Sözer, M. A., Altun, N. (2012) Terörle Mücadelede Mikro ve Makro Perspektifler. Ankara: Polis Akademisi Yayınları.

Bezić, H., Galović, T., Mišević, P. (2016) The Impact of Terrorism on the FDI of the EU and EEA Countries, Zbornik radova Ekonomskog Fakulteta u Rijeci: časopis za ekonomsku teoriju $i$ praksu/Proceedings of Rijeka Faculty of Economics: Journal of Economics and Business, Vol. 34, No. 2, pp. 333-362, doi: 10.18045/zbefri.2016.2.333.

Blomberg, S. B., Hess, G. D., Orphanides, A. (2004) "The Macroeconomic Consequences of Terrorism", Journal of Monetary Economics, Vol. 51, No. 5, pp. 1007-1032, doi: 10.1016/j.jmoneco.2004.04.001.

Caşın, M. H. (2008) Uluslararası Terörizm, Ankara: Nobel Yayın Dağıtım.

Dedeoğlu, B. (2003) "Terörizm üzerine karşılaştırmalar: Bermuda şeytan üçgeni”. In Dedeoğlu, B. ed., Dünden bugüne avrupa birliği, İstanbul: Boyut Kitapları.

Eckstein, Z., Tsiddon, D. (2004) "Macroeconomic Consequences of Terror: Theory and the Case of Israel", Journal of Monetary Economics, Vol. 51, No. 5, pp. 971-1002, doi: 10.1016/j.jmoneco.2004.05.001.

Frey, B. S., Luechinger, S., Stutzer, A. (2007) "Calculating Tragedy: Assessing the Costs of Terrorism", Journal of Economic Survey, Vol. 21, No. 1, pp. 1-24, doi: 10.1111/j.1467-6419.2007.00505.x.

Gaibulloev, K., Sandler, T. (2009) "The Impact of Terrorism and Conflicts on Growth in Asia". Economics and Politics, Vol. 21, No. 3, pp. 359-383, doi: 10.1111/j.1468-0343.2009.00347.x.

Gries, T., Krieger, T. Meierrieks, D. (2011) "Causal Linkages between Domestic Terrorism and Economic Growth", Defence and Peace Economics, Vol. 22, No. 5, pp. 493-508, doi: 10.1080/10242694.2010.532943.

Gupta, S. et al. (2004) "Fiscal Consequences of Armed Conflict and Terrorism in Low- and Middle-Income Countries", European Journal of Political Economy, Vol. 20, No. 2, pp. 403-421, doi: 10.1016/j.ejpoleco.2003.12.001. 
Karaduman, S., Batu, N. M. (2011) “Televizyon Haberlerinde Terörizm Olgusunun TRT’nin Haber Söylemi Bağlamında İncelenmesi”, Selçuk Üniversitesi Sosyal Bilimler Enstitüsü Dergisi, Vol. 25, pp. 359-374. Available at: <http:// dergisosyalbil.selcuk.edu.tr/susbed/article/view/207/191> [Accessed: March 29, 2017].

Karagöz, H. (2016) "Terörizmin Türkiye'de Turistler ve Turizm Gelirleri Üzerindeki Etkileri”, Dış Ticaret Enstitüsü Working Paper, Working Paper Series, No: 19/2016-04. Available at: <http://www.ticaret.edu.tr/uploads/ dosyalar/921/6.pdf> [Accessed: March 29, 2017].

Kılıç, Z. (2007) Küresellesme ile ivme kazanan uluslar arasıterörizm ve buna karşı alınan tedbirler, Yüksek Lisans Tezi, Isparta: Süleyman Demirel Üniversitesi Sosyal Bilimler Enstitüsü.

Kutlu, R. (2010) Uluslararası terörizm ve 11 eylül sonrasında türkiye'nin terörizmle mücadelesi, Yüksek Lisans Tezi, Trabzon: Karadeniz Teknik Üniversitesi Sosyal Bilimler Enstitüsü.

Michael, S. (2007) "Terrorism a Socio-Economic and Political Phenomenon with Special Reference to Pakistan", Journal of Management and Social Sciences, Vol. 3, No. 1, pp. 35-46. Available at: <http://pakistansocietyofvictimology.org/ Userfiles/Terrorism-\%20A\%20socio-\%20economic\%20and\%20political $\% 20$ Phenomenon.pdf $>$ [Accessed: March 29, 2017].

Meierrieks, D., Gries, T. (2012) "Economic Performance and Terrorist Activity in Latin America", Defence and Peace Economics, Vol. 23, No. 5, pp. 447-470, doi: 10.1080/10242694.2012.656945.

Musayev, V. (2016) "Externalities in Military Spending and Growth: The Role of Natural Resources as a Channel through Conflict", Defence and Peace Economics, Vol. 27, No. 3, pp. 378-391, doi: 10.1080/10242694.2014.994833.

Öcal, N., Y1ldırım, J. (2010) "Regional Effects of Terrorism on Economic Growth in Turkey: A Geographically Weighted Regression Approach", Journal of Peace Research, Vol. 47, No. 4, pp. 477-489, doi: 10.1177/0022343310364576.

Persitz, D. (2006) "The Effect of Terrorism on the Economy: Counterfactual Analysis of Israel", Seminar in Tel Aviv University, Manuscript, pp. 1-55. Available at: <http://www.tau.ac.il/ persitzd/TER.pdf> [Accessed: March 29, 2017].

Sezgin, S. (2003) “Savunma Harcamalar1, Terörizm ve Ekonomi”, Stradigma Aylık Strateji ve Analiz Dergisi, Vol. 4, pp. 3-5.

Tavares, J. (2004) "The Open Society Assesses Its Enemies: Shocks, Disasters and Terrorist Attacks", Journal of Monetary Economics, Vol. 51, No. 5, pp. 1039 1070, doi: 10.1016/j.jmoneco.2004.04.009.

Topal, A. H. (2004) Uluslararası hukukta devlet destekli terörizme karşı kuvvet kullanma, Doktora Tezi, Ankara: Ankara Üniversitesi Sosyal Bilimler Enstitüsü. 
Uysal, D., Mucuk, M., Gerçeker, M. (2009) "Terörizmin ekonomik etkileri: Türkiye”. Uluslararası Davraz Kongresi: Küresel Diyalog, Süleyman Demirel Üniversitesi, 24-27 Sep. 2009, pp. 1-15.

Uytun, A. (2009) 11 Eylül 2001 terör saldırısı sonrası değişen terörizm algısı, Yüksek Lisans Tezi, Ankara: Ufuk Üniversitesi Sosyal Bilimler Enstitüsü.

World Development Indicators, (2016) International Bank for Reconstruction and Development, Washington DC: World Bank Group.

Yalçınkaya, İ. A. (2008) Medya-terörizm ilişkisi, Yüksek Lisans Tezi, Trabzon: Karadeniz Teknik Üniversitesi Sosyal Bilimler Enstitüsü.

Yeniçeri, Z., Dönmez, A. (2008) "Terörizm ve Terörist Algısı: Silahı Kimin Tuttuğu Ne Kadar Etkili?”. Türk Psikoloji Dergisi, Vol. 23, No. 62, pp. 93103. Available at: <https://www.researchgate.net/publication/267562250> [Accessed: March 29, 2017].

Yıldırım, J., Öcal, N. (2013) "Analysing the Determinants of Terrorism in Turkey Using Geographically Weighted Regression", Defence and Peace Economics, Vol. 24, No. 3, pp. 195-209, doi: 10.1080/10242694.2012.695034.

Younas, J. (2015) "Does Globalization Mitigate the Adverse Effects of Terrorism on Growth", Oxford Economic Papers, Vol 67, No. 1, pp. 133-156, doi: 10.1093/ oep/gpu040. 


\title{
Utjecaj terorističkih napada na gospodarski rast: panel regresijska analiza
}

\author{
Mehmet Çinar ${ }^{1}$
}

\section{Sažetak}

Cilj ovog istraživanja je ispitati učinke terorističkih aktivnosti diljem svijeta na ekonomski rast. Točnije, ovi teroristički napadi i njihovi učinci na gospodarski rast $u$ većini zemalja klasificiraju se prema dohotku. U tom smislu, provodimo ispitivanje panela (FE i RE modeli) kako bismo analizirali broj terorističkih incidenata u tim zemljama i raspon podataka u periodu od 2000. do 2015. godine, a koji obuhvaća ukupno 115 zemalja. Rezultati istraživanja su u skladu s drugim nalazima u literaturi. Ti teroristički napadi uzrokuju negativan utjecaj na gospodarski rast u većini zemalja, posebice u zemljama s niskim prihodima. Općenito, rezultati pokazuju da su zemlje s niskim prihodima pogođene oko tri puta više od zemaljas visokim dohotkom kao rezultat tih terorističkih napada.

Ključne riječi: teror, terorizam, gospodarski rast, panel podaci, FE i RE modeli

JEL klasifikacija: C23, F52, H1, O4

${ }_{1}$ Izvanredni profesor, Faculty of Economics and Administrative Sciences, Department of Econometrics, Uludag University, 16059 Gorukle Campus, Bursa, Turska. Znanstveni interes: analiza panel podataka, analiza vremenskih serija, primijenjena ekonometrija, predviđanja. Tel.: +902242941108.Fax: +9022429410 03.E-mail: mcinar@uludag.edu.tr. 
Mehmet Çinar - The effects of terrorism on economic growth: Panel data approach Zb. rad. Ekon. fak. Rij. • $2017 \cdot$ vol. $35 \cdot$ no. $1 \cdot 97-121$

\section{Appendices}



Mehmet Çinar • The effects of terrorism on economic growth: Panel data approach

Table A1: Data set description of the series

\begin{tabular}{|l|r|r|r|r|}
\hline \multicolumn{1}{|c|}{ Income Groups } & \multicolumn{1}{c|}{ Mean } & \multicolumn{1}{c|}{ Std. Dev. } & Minimum & Maximum \\
\hline GRW & High Income Countries \\
\hline TERROR & 2.809184 & 4.072657 & -14.81000 & 26.28000 \\
\hline \multicolumn{5}{|c|}{ Upper Middle Income Countries } \\
\hline GRW & 4.199255 & 4.457962 & -8.120000 & 61.48000 \\
\hline TERROR & 0.815877 & 1.315623 & 0.000000 & 6.156979 \\
\hline \multicolumn{7}{|c|}{ Low Middle Income Countries } \\
\hline GRW & 4.676875 & 2.526934 & -12.77000 & 16.58000 \\
\hline TERROR & 1.678583 & 2.087782 & 0.000000 & 7.702556 \\
\hline \multicolumn{7}{|c|}{ Low Income Countries } \\
\hline GRW & 5.549766 & 9.909577 & -18.46000 & 143.8100 \\
\hline TERROR & 0.834663 & 1.291245 & 0.000000 & 4.804021 \\
\hline \multicolumn{7}{|c|}{ All Countries } \\
\hline GRW & 3.894538 & 5.246498 & -18.46000 & 143.8100 \\
\hline TERROR & 1.017361 & 1.541534 & 0.000000 & 7.702556 \\
\hline
\end{tabular}

Source: Author's calculation

Table A2: The detailed high income countries model estimation results

\begin{tabular}{|c|c|c|c|c|}
\hline \multicolumn{5}{|c|}{ Dependent Variable: GRW } \\
\hline \multicolumn{5}{|c|}{ Method: Panel EGLS (Cross-section random effects) } \\
\hline \multicolumn{5}{|l|}{ Sample: 20002015} \\
\hline \multicolumn{5}{|l|}{ Periods included: 16} \\
\hline \multicolumn{5}{|c|}{ Cross-sections included: 49} \\
\hline \multicolumn{5}{|c|}{ Total panel (balanced) observations: 784} \\
\hline \multicolumn{5}{|c|}{ Swamy and Arora estimator of component variances } \\
\hline Variable & Coefficient & Std. Error & t-Statistic & Prob. \\
\hline $\mathrm{C}$ & 2.979548 & 0.299472 & 9.949338 & 0.0000 \\
\hline TERROR & -0.198084 & 0.156232 & -1.267883 & 0.2052 \\
\hline \multicolumn{5}{|c|}{ Effects Specification } \\
\hline & & & S.D. & Rho \\
\hline Cross-section random & & & 1.622858 & 0.1582 \\
\hline Idiosyncratic random & & & 3.744051 & 0.8418 \\
\hline \multicolumn{5}{|c|}{ Weighted Statistics } \\
\hline R-squared & 0.002054 & \multirow{2}{*}{\multicolumn{2}{|c|}{ Mean dependent var }} & 1.403529 \\
\hline Adjusted R-squared & 0.000778 & & & 3.743139 \\
\hline S.E. of regression & 3.741683 & \multicolumn{2}{|c|}{ Sum squared resid } & 10948.15 \\
\hline F-statistic & 1.609564 & \multicolumn{2}{|c|}{ Durbin-Watson stat } & 1.185168 \\
\hline Prob (F-statistic) & 0.204931 & & & \\
\hline
\end{tabular}

Source: Author's calculation 
Table A3: The detailed upper middle income countries model estimation results

\begin{tabular}{|c|c|c|c|c|}
\hline \multicolumn{5}{|c|}{ Dependent Variable: GRW } \\
\hline \multicolumn{5}{|c|}{ Method: Panel EGLS (Cross-section random effects) } \\
\hline \multicolumn{5}{|c|}{ Sample: 20002015} \\
\hline \multicolumn{5}{|l|}{ Periods included: 16} \\
\hline \multicolumn{5}{|c|}{ Cross-sections included: 26} \\
\hline \multicolumn{5}{|c|}{ Total panel (balanced) observations: 416} \\
\hline \multicolumn{5}{|c|}{ Swamy and Arora estimator of component variances } \\
\hline Variable & Coefficient & Std. Error & t-Statistic & Prob. \\
\hline $\mathrm{C}$ & 4.413345 & 0.353189 & 12.49570 & 0.0000 \\
\hline TERROR & -0.262406 & 0.202857 & -1.293550 & 0.1965 \\
\hline \multicolumn{5}{|c|}{ Effects Specification } \\
\hline & & & S.D. & Rho \\
\hline \multicolumn{3}{|l|}{ Cross-section random } & 1.170063 & 0.0686 \\
\hline Idiosyncratic random & & & 4.311955 & 0.9314 \\
\hline \multicolumn{5}{|c|}{ Weighted Statistics } \\
\hline R-squared & 0.004032 & \multicolumn{2}{|c|}{ Mean dependent var } & 2.845320 \\
\hline Adjusted R-squared & 0.001626 & \multicolumn{2}{|c|}{\begin{tabular}{|l|} 
S.D. dependent var \\
\end{tabular}} & 4.311900 \\
\hline S.E. of regression & 4.308392 & \multicolumn{2}{|c|}{ Sum squared resid } & 7684.768 \\
\hline F-statistic & 1.676040 & \multirow{2}{*}{\multicolumn{2}{|c|}{ Durbin-Watson stat }} & 1.985103 \\
\hline Prob (F-statistic) & 0.196173 & & & \\
\hline
\end{tabular}

Source: Author's calculation

Table A4: The detailed lower middle income countries model estimation results

\begin{tabular}{|c|c|c|c|c|}
\hline \multicolumn{5}{|c|}{ Dependent Variable: GRW } \\
\hline \multicolumn{5}{|c|}{ Method: Panel EGLS (Cross-section weights) } \\
\hline \multicolumn{5}{|l|}{ Sample: 20002015} \\
\hline \multicolumn{5}{|l|}{ Periods included: 16} \\
\hline \multicolumn{5}{|c|}{ Cross-sections included: 24} \\
\hline \multicolumn{5}{|c|}{ Total panel (balanced) observations: 384} \\
\hline \multicolumn{5}{|c|}{ Linear estimation after one-step weighting matrix } \\
\hline Variable & Coefficient & Std. Error & t-Statistic & Prob. \\
\hline $\mathrm{C}$ & 5.252388 & 0.144671 & 36.30586 & 0.0000 \\
\hline TERROR & -0.342857 & 0.075663 & -4.531384 & 0.0000 \\
\hline \multicolumn{5}{|c|}{ Weighted Statistics } \\
\hline R-squared & 0.494554 & \multicolumn{2}{|c|}{ Mean dependent var } & 7.067713 \\
\hline Adjusted R-squared & 0.460764 & \multicolumn{2}{|c|}{ S.D. dependent var } & 5.357808 \\
\hline S.E. of regression & 2.182791 & \multicolumn{2}{|c|}{ Sum squared resid } & 1710.483 \\
\hline F-statistic & 14.63599 & \multicolumn{2}{|c|}{ Durbin-Watson stat } & 1.435044 \\
\hline Prob (F-statistic) & 0.000000 & & & \\
\hline
\end{tabular}

Source: Author's calculation 
Mehmet Çinar • The effects of terrorism on economic growth: Panel data approach

Table A5: The detailed lower income countries model estimation results

\begin{tabular}{|c|c|c|c|c|}
\hline \multicolumn{5}{|c|}{ Dependent Variable: GRW } \\
\hline \multicolumn{5}{|c|}{ Method: Panel EGLS (Cross-section weights) } \\
\hline \multicolumn{5}{|l|}{ Sample: 20002015} \\
\hline \multicolumn{5}{|l|}{ Periods included: 16} \\
\hline \multicolumn{5}{|c|}{ Cross-sections included: 16} \\
\hline \multicolumn{5}{|c|}{ Total panel (balanced) observations: 256} \\
\hline \multicolumn{5}{|c|}{ Linear estimation after one-step weighting matrix } \\
\hline Variable & Coefficient & Std. Error & t-Statistic & Prob. \\
\hline $\mathrm{C}$ & 5.985856 & 0.270360 & 22.14031 & 0.0000 \\
\hline TERROR & -0.522474 & 0.253231 & -2.063236 & 0.0402 \\
\hline \multicolumn{5}{|c|}{ Weighted Statistics } \\
\hline R-squared & 0.362307 & \multicolumn{2}{|c|}{ Mean dependent var } & 14.27285 \\
\hline Adjusted R-squared & 0.319616 & \multicolumn{2}{|c|}{ S.D. dependent var } & 13.18129 \\
\hline S.E. of regression & 9.055110 & \multicolumn{2}{|c|}{ Sum squared resid } & 19596.81 \\
\hline F-statistic & 8.486764 & \multicolumn{2}{|c|}{ Durbin-Watson stat } & 1.845270 \\
\hline Prob (F-statistic) & 0.000000 & & & \\
\hline
\end{tabular}

Source: Author's calculation

Table A6: The detailed all countries model estimation results

\begin{tabular}{|c|c|c|c|c|}
\hline \multicolumn{5}{|c|}{ Dependent Variable: GRW } \\
\hline \multicolumn{5}{|c|}{ Method: Panel EGLS (Cross-section weights) } \\
\hline \multicolumn{5}{|l|}{ Sample: 20002015} \\
\hline \multicolumn{5}{|l|}{ Periods included: 16} \\
\hline \multicolumn{5}{|c|}{ Cross-sections included: 115} \\
\hline \multicolumn{5}{|c|}{ Total panel (balanced) observations: 1840} \\
\hline \multicolumn{5}{|c|}{ Linear estimation after one-step weighting matrix } \\
\hline Variable & Coefficient & Std. Error & t-Statistic & Prob. \\
\hline $\mathrm{C}$ & 4.268188 & 0.074949 & 56.94801 & 0.0000 \\
\hline TERROR & -0.367273 & 0.058163 & -6.314558 & 0.0000 \\
\hline \multicolumn{5}{|c|}{ Weighted Statistics } \\
\hline R-squared & 0.484725 & \multicolumn{2}{|c|}{ Mean dependent var } & 7.986029 \\
\hline Adjusted R-squared & 0.450353 & \multicolumn{2}{|c|}{ S.D. dependent var } & 8.803584 \\
\hline S.E. of regression & 4.892566 & \multicolumn{2}{|c|}{ Sum squared resid } & 41267.73 \\
\hline F-statistic & 14.10249 & \multicolumn{2}{|c|}{ Durbin-Watson stat } & 1.594516 \\
\hline Prob (F-statistic) & 0.000000 & & & \\
\hline
\end{tabular}

Source: Author's calculation 